Technological University Dublin

DÜBLIN

ARROW@TU Dublin

Articles

School of Accounting and Finance

2020

\title{
Brent Crude Oil Prices Volatility During Major Crises
}

Miroslava Zavadska

Moravian Business College, Olomouc

Lucia Morales

Technological University Dublin, lucia.morales@tudublin.ie

Joseph Coughlan

National University of Ireland, Maynooth

Follow this and additional works at: https://arrow.tudublin.ie/buschacart

Part of the Accounting Commons

\section{Recommended Citation}

Zavadsk, M., Morales. L. \& Coughlan, J. (2020). Brent crude oil prices volatility during major crises.

Finance Research Letters, 32, 101078. doi:10.1016/j.frl.2018.12.026

This Article is brought to you for free and open access by

the School of Accounting and Finance at ARROW@TU

Dublin. It has been accepted for inclusion in Articles by

an authorized administrator of ARROW@TU Dublin. For

more information, please contact

arrow.admin@tudublin.ie, aisling.coyne@tudublin.ie,

gerard.connolly@tudublin.ie.

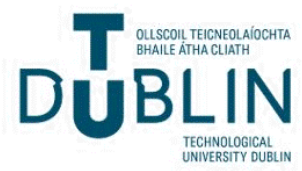




\title{
Brent crude oil prices volatility during major crises
}

\author{
Miroslava Zavadska $^{\mathrm{a}, *}$, Lucía Morales ${ }^{\mathrm{b}}$, Joseph Coughlan ${ }^{\mathrm{c}}$ \\ ${ }^{a}$ Moravian Business College Olomouc, Czech Republic \\ ${ }^{\mathrm{b}}$ College of Business, Technological University Dublin, Ireland \\ ${ }^{\mathrm{c}}$ School of Business, Maynooth University, Ireland
}

\section{A R T I C L E I N F O}

\section{Keywords:}

Crude oil

Volatility

Energy

Crises

JEL codes:

G01

G17

Q40

\begin{abstract}
A B S T R A C T
Volatility patterns in Brent crude oil spot and futures prices are examined during four major crises that significantly affected the oil markets: the First Gulf war 1990/91; the Asian Financial crisis 1997/98; the US terrorist attack 2001; and the Global Financial crisis 2008/9. The selected crises arose due to different triggers having diverse implications for oil market participants. The outcomes reveal higher levels of volatility during crises that was directly associated with oil supply/demand disruptions and higher volatility persistence during financial/economic crises, indicating that volatility persistence is a key issue when uncertainty is derived from global economic and financial instability.
\end{abstract}

\section{Introduction}

Oil is an indispensable energy resource fuelling economic growth and development, and industrialised and developed economies consider it to be a key driver of their economies. Oil prices are determined by demand and supply levels, but also they are affected by sources of natural volatility including business cycles, speculative activities, and political influences (Oberndorfer, 2009; Hamilton, 2014; Robe and Wallen, 2016). These factors have major implications for strategic decisions taken by investors, hedgers, speculators and governments, who need to be aware of phases of higher volatility, where greater levels of risk and uncertainty are exhibited in the market, thus conditioning their decision making processes (Sadorsky, 2006; Salisu and Fasanya, 2013; Zhang and Wang, 2013; Morales and Andreosso-O'Callaghan, 2014; Evgenidis, 2018). Crude oil prices have encountered extreme volatility over the past decades due to numerous factors, such as wars and political instability, economic and financial slowdowns, terrorist attacks, and natural disasters. This study is the first to consider the relationship between spot and future prices during four specific periods of turmoil characterised by major changes in oil prices: namely the Gulf war, the Asian Crisis, the US terrorist attack and the Global Financial Crisis.

There has been a significant upsurge in research studies focussed on volatility modelling, as academics and practitioners are acutely aware of the significance of understanding financial market volatility (Oberndorfer, 2009; Ozdemir et al., 2013; Salisu and Fasanya, 2013; Zhang and Wang, 2013; Charles and Darné, 2014; Wang et al., 2016; Ozdemir et al., 2013). Ozdemir et al. (2013) considered both Brent spot and futures price volatility persistence from the 1990s until 2011, finding that volatility was very persistent in both spot and futures prices. Their findings also suggest that spot and futures prices can change in an unpredictable manner in the long run, which indicates that there is little potential for arbitrage in the oil market. Similarly, Charles and Darné (2014) studied volatility persistence from 1985 until 2011. Their research suggests that structural breaks affecting the series impact the estimation of volatility persistence, which adds to our understanding of volatility in crude oil markets. Lee et al. (2006) evaluated the

\footnotetext{
* Corresponding author.

E-mail addresses: miroslava.zavadska@mvso.cz (M. Zavadska), lucia.morales@dit.ie (L. Morales), joseph.coughlan@mu.ie (J. Coughlan).
} 


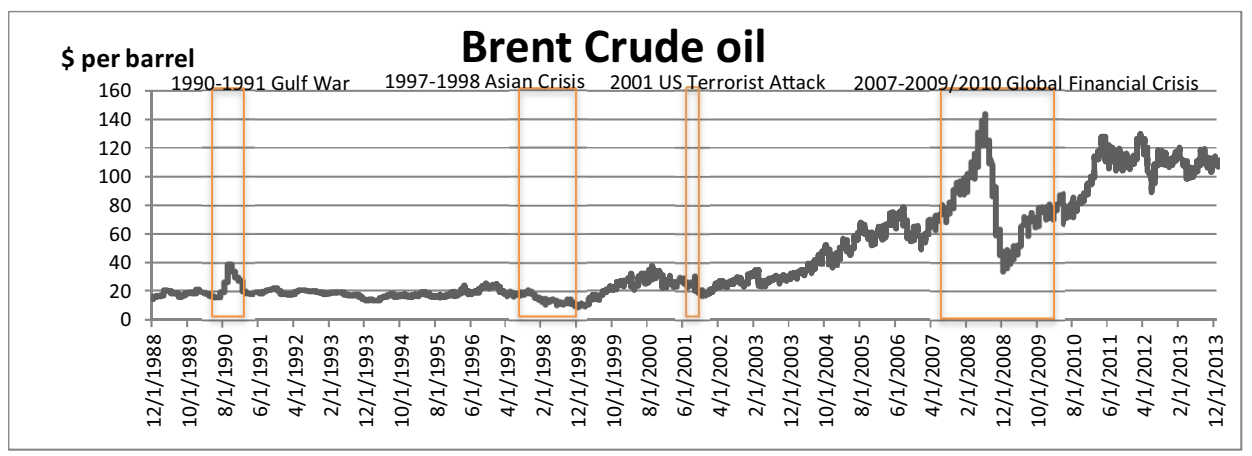

Fig. 1. Historical development of brent crude oil price. Source: Thompson Reuters Datastream (graphical adjustments added by the authors, 2018).

existence of these breaks finding them to be of great importance to individuals and firms who are concerned about how well they can manage the risks associated with frequent changes in oil prices. Narayan and Narayan (2007) were one of the first to model and forecast oil price volatility using different sub-samples. The presence of structural break points confirms abnormal behaviour in the series, which indicates higher uncertainty, and an elevated level of risk which should be accounted for by concerned groups of investors, speculators and policy makers. This paper explicitly considers the importance of structural breaks when modelling oil volatility through applying multiple break points to analyse all four shock periods, as depicted in Fig. 1.

The four episodes were chosen for analysis, as they are associated with periods of significant changes in oil prices. The Gulf War showed a $100 \%$ swing in prices during the period, and the other three crises all had a minimum movement in price of over $35 \%$ during the crisis period. During times of high uncertainty derived from terrorism, violence or radicalisation activities, commodity markets, such as oil, experience a surge on prices fluctuations (Orbaneja et al., 2018), and the process of managing risks becomes of vital importance for economic agents that aim to maximise their gains while they minimise their losses.

In this paper, we address the issue of volatility persistence during times of crisis by implementing a robust approach to analyse four crises of different natures and magnitudes. Two of the crises had a direct impact on supply and demand for oil (Gulf War 1990 and US Terrorist attack 2001), whereas the other crises under investigation (Asian Crisis and Global Financial Crisis) affected the oil market through the financial markets. Díaz and Pérez García (2017) demonstrate that oil price shocks affect the returns of oil and gas companies listed on the NYSE. We use different methods to show that while volatility is affected by crisis periods, more importantly, the type of crisis influences volatility persistence. Furthermore, we test for asymmetric effects, through the T-GARCH model, and find differences between the impact of negative and positive news according to the type of crisis. The unique contribution of this paper emanates from the analysis of the four different events focussing on the behaviour of the series for the whole period, and the periods before, during and after the crisis episode took place, as such a study has not been carried out in the extant literature. We have conducted a widespread review of existing research in the field and this is the first attempt to understand evidence of the behaviour of oil markets in such a comprehensive manner for these types of events.

The remainder of the paper is organised as follows: Section 2 explains the data set and methodologies implemented. Section 3 presents and discusses the obtained empirical results; while Section 4 concludes the paper.

\section{Data and methodology}

The data set consists of daily closing spot prices and continuous futures prices for the Brent crude oil market as Brent is considered the global crude oil benchmark (Dowling et al., 2016). The data was obtained from Thompson Reuters Datastream and are shown in US dollars per barrel. The whole data sample spans from 7th December 1988 to 31st December 2013, which offers 6,540 observations. The use of daily data is particularly relevant for volatility analysis (Salisu and Fasanya, 2013; Charles and Darné, 2014) as higher frequency data is needed in order to accurately capture market changes. The study begins with a standard analysis of the properties of the selected series. It is followed by formal tests including the VAR framework used to identify the optimal lag length for each variable, the Augmented Dickey-Fuller (ADF) test for stationarity and the Bai-Perron structural break test. The outcomes of the structural break tests are shown in Table 1. This is followed by the volatility modelling using the GARCH, T-GARCH and OLS approaches.

\subsection{Volatility models}

The univariate models used for forecasting crude oil prices in this study are the Generalised Autoregressive Conditional Heteroskedasticity (GARCH) presented by Bollerslev (1986), the Threshold GARCH (T-GARCH) model by Zakoian (1994) and the Ordinary Least Squares (OLS) regression by Johnson (1960), which is used when there is no ARCH effect in our series. The ARCH model presented by Engle (1982) suggests that the variance of the residuals at the time $t$ depends on the squared error terms from past periods. The ARCH (q) model specification is presented in Eq. (2) below:

$$
y_{t}=\alpha+\beta^{\prime} x_{t}+\varepsilon_{t}
$$


Table 1

Structural break points- Bai-Perron Test.

\begin{tabular}{ll}
\hline Research sample & Breakpoints \\
\hline $\begin{array}{l}\text { The Gulf war } \\
\text { Whole Period }\end{array}$ & $7 / 12 / 1988$ to $12 / 04 / 1996$ \\
$\begin{array}{l}\text { Pre-crisis } \\
\text { Crisis }\end{array}$ & $7 / 12 / 1988$ to $27 / 09 / 1990$ \\
Post-crisis & $28 / 09 / 1990$ to $1 / 04 / 1991$ \\
\hline The Asian crisis & $2 / 04 / 1991$ to $12 / 04 / 1996$ \\
\hline Whole Period & \\
Pre-crisis & \\
Crisis & $30 / 05 / 1995$ to $4 / 07 / 2000$ \\
Post-crisis & $30 / 05 / 1995$ to $12 / 09 / 1996$ \\
\hline US terrorist attack, 2001 & $13 / 09 / 1996$ to $13 / 01 / 2000$ \\
\hline Whole Period & $14 / 01 / 2000$ to $4 / 07 / 2000$ \\
Pre-crisis & \\
Crisis & $12 / 09 / 2000$ to $13 / 03 / 2003$ \\
Post-crisis & $12 / 09 / 2000$ to $16 / 09 / 2001$ \\
\hline The Global Financial crisis & $17 / 09 / 2001$ to $8 / 02 / 2002$ \\
\hline Whole Period & $9 / 02 / 2002$ to $13 / 03 / 2003$ \\
Pre-crisis & \\
Crisis & \\
Post-crisis & $1 / 01 / 2003$ to $31 / 12 / 2013$ \\
\hline & $1 / 01 / 2003$ to $28 / 08 / 2007$ \\
\hline & $29 / 08 / 2007$ to $28 / 01 / 2009$ \\
& $29 / 01 / 2009$ to $31 / 12 / 2013$ \\
\hline
\end{tabular}

where, $\varepsilon_{t} \mid \Omega_{t} \sim \operatorname{iid} N\left(0, h_{t}\right)$, and

$$
h_{t}=\gamma_{0}+\sum_{j=1}^{q} \gamma_{j \varepsilon_{t-j}^{2}}^{2}
$$

The generalised ARCH model by Bollerslev (1986) known as GARCH (p, q) is outlined as follows:

$$
y_{t}=\alpha+\beta^{\prime} x_{t}+\varepsilon_{t}
$$

where, $\varepsilon_{t} \mid \Omega_{t} \sim \operatorname{iid} N\left(0, h_{t}\right)$, and

$$
h_{t}=\omega+\sum_{i=1}^{p} \alpha_{i} h_{t-i}+\sum_{j=1}^{q} \gamma_{j \varepsilon_{t-j}^{2}}
$$

This states that the value of the variance scaling parameter now depends both on past values of the shocks, which are captured by the lagged squared residual terms, and on the past values of itself, which are captured by lagged terms. The simplest form of GARCH (p, q) model is the GARCH $(1,1)$, which is commonly used by many researchers in oil markets, as it generally performs better than higher order GARCH models (Lee et al., 2006; Narayan and Narayan, 2007; Salisu and Fasanya, 2013), for which the variance equation is:

$$
h_{t}=\omega+\alpha \varepsilon_{t-1}^{2}+\beta h_{t-1}
$$

The ARCH and the GARCH models are symmetric; however, it has been observed that negative shocks have larger impact on volatility than positive shocks in most financial time series such as stocks and commodities. Therefore, in order to test for asymmetries in the conditional variance the T-GARCH model was deemed appropriate and included in this analysis. The specification of the conditional variance equation for T-GARCH $(1,1)$ is given by:

$$
h_{t}=\omega+\alpha \varepsilon_{t-1}^{2}+\theta \varepsilon_{t-1}^{2} d_{t-1}+\beta h_{t-1}
$$

where, $d_{t}$ takes the value of 1 for $\varepsilon_{t}<0$, and 0 otherwise. This means that positive and negative shocks have different impacts. Positive news has an impact of $\alpha$, whereas negative shocks have an impact of $\alpha+\theta$. We also apply the Ordinary Least Squares (OLS) method, which is a model that assumes the existence of constant variance, an assumption that needs to be considered carefully in the context of this study, as time series are characterised by exhibiting heteroskedastic behaviour. The OLS regression introduced by Johnson (1960) is one of the initial approaches used to model volatility behaviour in time series, and it is applied in this study for comparative reasons and only when the samples are too small to allow the ARCH and GARCH type models to run. 

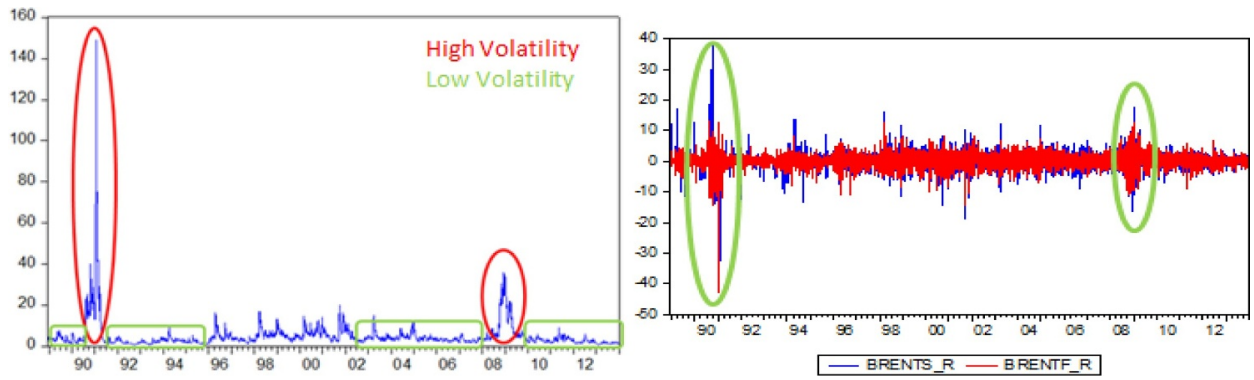

Fig. 2. Examples of volatility clustering. Source: Thompson Reuters Datastream and Eviews 8 (graphical adjustments added by the authors, 2018).

\section{Empirical findings}

The data series shows strong evidence of volatility clustering, where periods of high volatility are followed by low volatility, a behaviour that is consistent with common findings in the extant literature (Charles and Darné, 2014). Volatility spikes are especially evident during the Gulf War and the Global Financial Crisis, as noted by Salisu and Fasanya (2013), where the returns of spot and futures oil prices show unsteady and more noticeable patterns than during the Asian Crisis and the US terrorist attack as per Fig. 2.

\subsection{Summary statistics}

The mean for spot and futures prices show a similar pattern for the whole period from December 1988 to December 2013. Spot prices are slightly more volatile than futures prices, but the differences are quite insignificant, showing that both series seem to behave in a similar fashion. During the Asian Crisis period, the results for the crisis period are surprising, as they show a near to zero mean, but positive outcomes at 0.007 for spot and 0.005 for futures returns. We would not expect this result, but this can be due to the fact that crisis period had a long duration ( 870 observations/days), which is the highest from all four shock periods, and it could have smoothed the effect of the fluctuations. The US terrorist attack period showed a negative mean for the pre-crisis and crisis subperiods for both spot and futures returns. This explains the decrease in spot and futures prices during this period. The Global Financial Crisis demonstrates similar patterns to the Gulf war period, where the mean is positive during the pre-crisis and post-crisis period for both returns and negative for the crisis period. Table 2 below identifies descriptive statistics for spot and futures prices and their returns.

\subsection{Volatility findings}

\subsubsection{GARCH $(1,1)$ outcomes}

The Gulf war period shows positive and significant volatility levels during the whole period of the Gulf war and also for post-crisis period for futures returns. However, this was not the case for spot returns. Higher volatility spikes were found for the whole period, but longer persistence was the main feature during the post-crisis period. The outcomes for the Asian Crisis are significant during the whole period for both returns, and for futures returns during the crisis sub-period. Higher volatility spikes are apparent for futures returns in the crisis sub-period compared to the whole period. The Gulf war period had higher impact on volatility spikes than the Asian Crisis. This indicates that indeed the Gulf war compressed the oil market by oil supply uncertainty more than the regional Asian Financial Crisis. The September 11 (2001) terrorist attack had an immediate impact on the oil market, however it had lower persistency than other shock periods under analysis. The outcomes for the Global Financial Crisis are significant and positive for all periods under study and for both spot and futures returns. The futures returns indicate lower volatility spikes than spot returns during pre-crisis. This indicates that in relatively stable periods, the spot returns appear to reach greater volatility highs than futures returns. This outcome of high volatility persistence in Brent crude oil is consistent with the findings of Salisu and Fasanya (2013) who points towards more variations of spot prices in the Brent trends. Tables 3-6 below represent the volatility outcomes.

\subsubsection{TGARCH $(1,1)$ outcomes}

During the Gulf war there was no significant leverage effect in any of the sub-periods. The Asian Crisis does not confirm the existence of asymmetries in our series but shows consistent results with the GARCH outcomes for the same sub-periods. During the September 11, 2001 crisis the GARCH $(1,1)$ model shows significant outcomes during the whole period for spot returns, which are confirmed by the T-GARCH model findings. However, the T-GARCH method does not show any evidence of leverage effects. The TGARCH $(1,1)$ approach is significant and positive for the Global Financial Crisis in the case of futures returns during the whole period indicating the existence of leverage effects. This finding suggests that negative news has a larger impact on volatility of oil than good news, which is consistent with findings of Wang and Wu (2012), and Salisu and Fasanya (2013). When applying the T-GARCH model to an out of sample dataset (for the period after the Global Financial Crisis) to test for leverage effect from February 2014 to July 2015 based on the Bai-Perron structural break outcomes, the findings (see Table A in appendix) did not show any significant results to confirm or reject leverage effects affecting the series as the model did not meet required stability conditions.

With the help of the OLS volatility model, we found that during the Gulf war period the model did not report any significant 


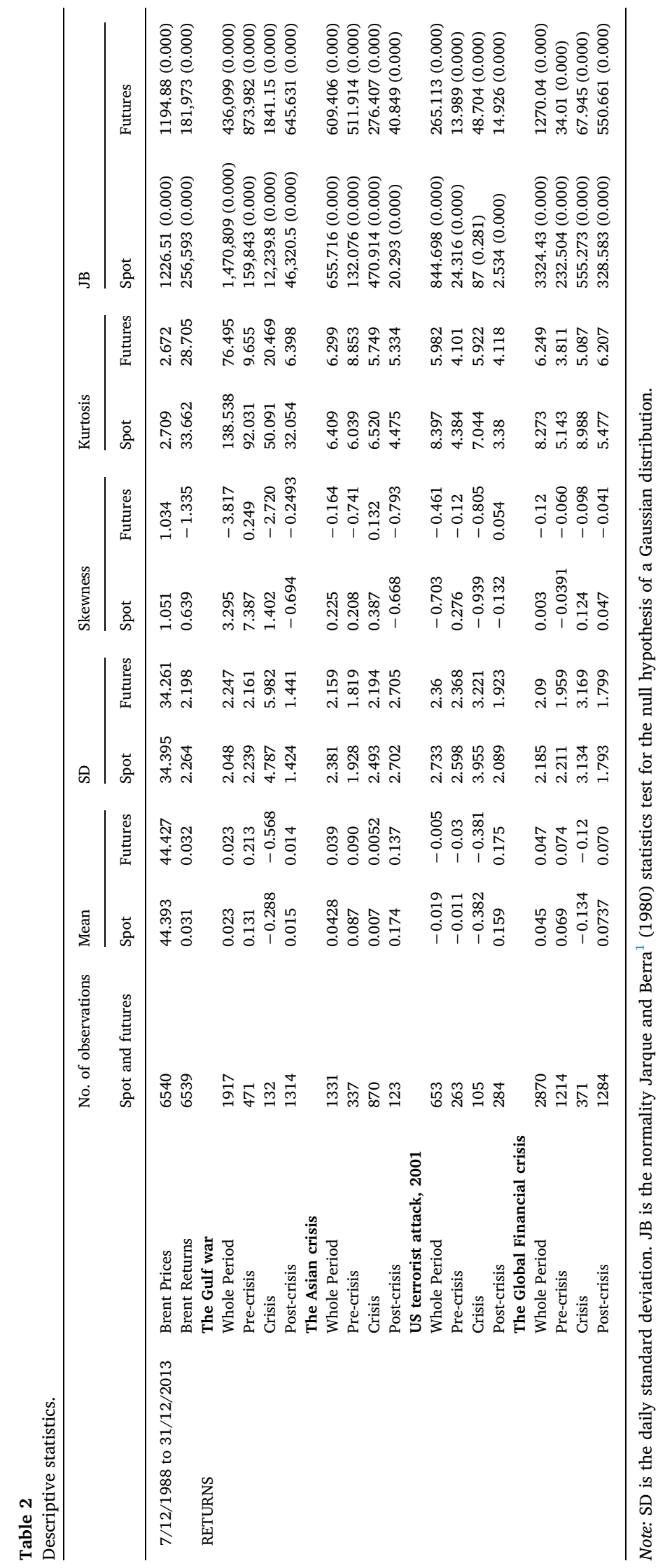


Table 3

Volatility models for the Gulf war.

\begin{tabular}{|c|c|c|c|c|c|c|c|c|c|}
\hline \multicolumn{10}{|l|}{ Volatility models } \\
\hline \multicolumn{10}{|l|}{ The Gulf war } \\
\hline & & \multicolumn{2}{|c|}{ Whole period } & \multicolumn{2}{|l|}{ Pre-crisis } & \multicolumn{2}{|l|}{ Crisis } & \multicolumn{2}{|l|}{ Post-crisis } \\
\hline & & Spot & Futures & Spot & Futures & Spot & Futures & Spot & Futures \\
\hline \multirow[t]{4}{*}{ GARCH $(1,1)$} & $\omega$ & $\begin{array}{l}2.6857^{*} \\
(0.0854)\end{array}$ & $\begin{array}{l}0.0681^{* * *} \\
(0.0061)\end{array}$ & $\begin{array}{l}2.7590 \\
(0.1385)\end{array}$ & $\begin{array}{l}0.2305 \\
(0.2552)\end{array}$ & $\begin{array}{l}10.947^{*} \\
(0.0621)\end{array}$ & $\begin{array}{l}10.447^{* * *} \\
(0.0171)\end{array}$ & $\begin{array}{l}0.2283^{*} \\
(0.0588)\end{array}$ & $\begin{array}{l}0.0259 * * \\
(0.0723)\end{array}$ \\
\hline & $\alpha$ & $\begin{array}{l}-0.0044 \\
(0.0000)\end{array}$ & $\begin{array}{l}0.1151^{* * *} \\
(0.0000)\end{array}$ & $\begin{array}{l}-0.0079 \\
(0.0027)\end{array}$ & $\begin{array}{l}0.1634^{* *} \\
(0.0213)\end{array}$ & $\begin{array}{l}-0.0189 \\
(0.0230)\end{array}$ & $\begin{array}{l}0.9886 \\
(0.1512)\end{array}$ & $\begin{array}{l}-0.0130 \\
(0.0000)\end{array}$ & $\begin{array}{l}0.0519^{* * *} \\
(0.0001)\end{array}$ \\
\hline & $\beta$ & $0.5937^{* *}$ & $0.8742^{* * *}$ & $0.6125^{*}$ & $0.7970^{* * *}$ & $0.4434 * *$ & $0.1522^{*}$ & $0.9109^{* * *}$ & $0.9384^{* * *}$ \\
\hline & & $(0.0404)$ & $(0.0000)$ & $(0.0942)$ & $(0.0000)$ & $(0.0160)$ & $(0.0952)$ & $(0.0000)$ & $(0.0000)$ \\
\hline \multirow[t]{8}{*}{ TGARCH $(1,1)$} & $\omega$ & $2.7110^{* * * *}$ & $0.0649 * * *$ & $3.2778^{* * *}$ & 0.2588 & $12.423^{*}$ & 6.2040 & $1.2732^{* * *}$ & $0.0285^{*}$ \\
\hline & & $(0.0007)$ & $(0.0027)$ & $(0.0101)$ & $(0.2206)$ & $(0.0717)$ & $(0.1556)$ & $(0.0062)$ & $(0.0679)$ \\
\hline & $\alpha$ & $0.0491^{*}$ & $0.1465^{* * *}$ & 0.0188 & $0.2168^{* *}$ & 0.0465 & 0.7805 & 0.0411 & $0.0663^{* *}$ \\
\hline & & $(0.0685)$ & $(0.0019)$ & $(0.4066)$ & $(0.0296)$ & $(0.7363)$ & $(0.3623)$ & $(0.4064)$ & $(0.0154)$ \\
\hline & $\theta$ & -0.0554 & -0.0764 & -0.0739 & -0.1119 & -0.0708 & -0.6135 & -0.0575 & -0.0211 \\
\hline & & $(0.0342)$ & $(0.0987)$ & $(0.0000)$ & $(0.2799)$ & $(0.6048)$ & $(0.4857)$ & $(0.2366)$ & $(0.5043)$ \\
\hline & $\beta$ & $0.5974^{* * *}$ & $0.8822^{* * *}$ & $0.5696^{* *}$ & $0.7872^{* * *}$ & $0.5116^{* *}$ & $0.5049 * * *$ & $0.5829 * * *$ & $0.9342^{* * *}$ \\
\hline & & $(0.0000)$ & $(0.0000)$ & $(0.0112)$ & $(0.0000)$ & $(0.0275)$ & $(0.0021)$ & $(0.0002)$ & $(0.0000)$ \\
\hline \multirow[t]{2}{*}{ OLS } & $\beta$ & -0.0056 & $\mathrm{n} / \mathrm{a}$ & -0.0109 & $\mathrm{n} / \mathrm{a}$ & -0.0101 & 0.0279 & 0.0144 & $\mathrm{n} / \mathrm{a}$ \\
\hline & & $(0.8075)$ & & $(0.8131)$ & & $(0.8433)$ & (0.7519) & $(0.6052)$ & \\
\hline
\end{tabular}

Note: $* * * * *, *$ represents statistical significance at $99 \%, 95 \%$ and $90 \%$ respectively. The OLS test was used to model.

volatility, not the returns, in cases where there was no ARCH effect in the series and in samples below 500. $n / a$ menas 'not applied'.

Table 4

Volatility models for the Asian crisis.

\begin{tabular}{|c|c|c|c|c|c|c|c|c|c|}
\hline \multicolumn{10}{|l|}{ Volatility models } \\
\hline \multicolumn{10}{|l|}{ The Asian crisis } \\
\hline & & \multicolumn{2}{|c|}{ Whole period } & \multicolumn{2}{|l|}{ Pre-crisis } & \multicolumn{2}{|l|}{ Crisis } & \multicolumn{2}{|l|}{ Post-crisis } \\
\hline & & Spot & Futures & Spot & Futures & Spot & Futures & Spot & Futures \\
\hline \multirow[t]{3}{*}{ GARCH $(1,1)$} & $\omega$ & $\begin{array}{l}0.1264 * \\
(0.0595)\end{array}$ & $\begin{array}{l}0.0249^{*} \\
(0.0722)\end{array}$ & $\begin{array}{l}0.2148 \\
(0.3037)\end{array}$ & $\begin{array}{l}0.0359 \\
(0.2700)\end{array}$ & $\begin{array}{l}0.0553 \\
(0.2371)\end{array}$ & $\begin{array}{l}0.2221 * * * \\
(0.0068)\end{array}$ & $\begin{array}{l}0.7309 \\
(0.5579)\end{array}$ & $\begin{array}{l}5.6620 * * \\
(0.0474)\end{array}$ \\
\hline & $\alpha$ & $\begin{array}{l}0.0599 * * \\
(0.0155)\end{array}$ & $\begin{array}{l}0.0393 * * * \\
(0.0031)\end{array}$ & $\begin{array}{l}0.0784 \\
(0.2873)\end{array}$ & $\begin{array}{l}0.0790^{*} \\
(0.0637)\end{array}$ & $\begin{array}{l}0.0377 \\
(0.1553)\end{array}$ & $\begin{array}{l}0.0480 * * \\
(0.0120)\end{array}$ & $\begin{array}{l}0.0901 \\
(0.5537)\end{array}$ & $\begin{array}{l}0.1601 \\
(0.4423)\end{array}$ \\
\hline & $\beta$ & $\begin{array}{l}0.9197^{* * * *} \\
(0.0000)\end{array}$ & $\begin{array}{l}0.9581^{* * *} \\
(0.0000)\end{array}$ & $\begin{array}{l}0.8659 * * * \\
(0.0000)\end{array}$ & $\begin{array}{l}0.9164 * * * \\
(0.0000)\end{array}$ & $\begin{array}{l}0.9543^{* * *} \\
(0.0000)\end{array}$ & $\begin{array}{l}0.9044 * * * \\
(0.0000)\end{array}$ & $\begin{array}{l}0.8148^{* * *} \\
(0.0044)\end{array}$ & $\begin{array}{l}0.0675 \\
(0.8444)\end{array}$ \\
\hline \multirow[t]{4}{*}{ TGARCH $(1,1)$} & $\omega$ & $\begin{array}{l}0.1259^{*} \\
(0.0650)\end{array}$ & $\begin{array}{l}0.0303^{*} \\
(0.0520)\end{array}$ & $\begin{array}{l}0.2209 \\
(0.3323)\end{array}$ & $\begin{array}{l}0.0337 \\
(0.2507)\end{array}$ & $\begin{array}{l}0.0247 \\
(0.5409)\end{array}$ & $\begin{array}{l}0.2212^{* * *} \\
(0.0077)\end{array}$ & $\begin{array}{l}9.2343^{* * *} \\
(0.0000)\end{array}$ & $\begin{array}{l}0.3477 \\
(0.1219)\end{array}$ \\
\hline & $\alpha$ & $\begin{array}{l}0.0549 * \\
(0.0717)\end{array}$ & $\begin{array}{l}0.0621 * * \\
(0.0223)\end{array}$ & $\begin{array}{l}0.0732 \\
(0.2469)\end{array}$ & $\begin{array}{l}0.1103 \\
(0.1496)\end{array}$ & $\begin{array}{l}0.0123 \\
(0.3999)\end{array}$ & $\begin{array}{l}0.0479 * * \\
(0.0415)\end{array}$ & $\begin{array}{l}0.3587^{* *} \\
(0.0429)\end{array}$ & $\begin{array}{l}-0.1081 \\
(0.0661)\end{array}$ \\
\hline & $\theta$ & $\begin{array}{l}0.0088 \\
(0.7741)\end{array}$ & $\begin{array}{l}-0.0343 \\
(0.2516)\end{array}$ & $\begin{array}{l}0.0120 \\
(0.9188)\end{array}$ & $\begin{array}{l}-0.0692 \\
(0.3406)\end{array}$ & $\begin{array}{l}0.0372 \\
(0.1001)\end{array}$ & $\begin{array}{l}0.0002 \\
(0.9932)\end{array}$ & $\begin{array}{l}-0.3213 \\
(0.0747)\end{array}$ & $\begin{array}{l}0.0223 \\
(0.8395)\end{array}$ \\
\hline & $\beta$ & $\begin{array}{l}0.9203^{* * *} \\
(0.0000)\end{array}$ & $\begin{array}{l}0.9524 * * * \\
(0.0000)\end{array}$ & $\begin{array}{l}0.8633^{* * *} \\
(0.0000)\end{array}$ & $\begin{array}{l}0.9230 * * * \\
(0.0000)\end{array}$ & $\begin{array}{l}0.9668^{* * *} \\
(0.0000)\end{array}$ & $\begin{array}{l}0.9046 * * * \\
(0.0000)\end{array}$ & $\begin{array}{l}-0.5163 \\
(0.0342)\end{array}$ & $\begin{array}{l}1.0526 \\
(0.0000)\end{array}$ \\
\hline OLS & $\beta$ & $\begin{array}{l}0.1496^{* * *} \\
(0.0000)\end{array}$ & $\mathrm{n} / \mathrm{a}$ & $\begin{array}{l}0.2082^{* * *} \\
(0.0001)\end{array}$ & $\begin{array}{l}0.0937^{*} \\
(0.0862)\end{array}$ & $\begin{array}{l}0.1338^{* * *} \\
(0.0001)\end{array}$ & $\mathrm{n} / \mathrm{a}$ & $\begin{array}{l}0.1395 \\
(0.1278)\end{array}$ & $\begin{array}{l}0.1178 \\
(0.1994)\end{array}$ \\
\hline
\end{tabular}

Note: $* * * * * * *$ represents statistical significance at $99 \%, 95 \%$ and $90 \%$ respectively. The OLS test was used to model.

volatility, not the returns, in cases where there was no ARCH effect in the series and in samples below 500. n/a menas 'not applied'.

results. However, the Asian Crisis period shows significant results during the whole period for spot returns and pre-crisis period for spot and futures returns, and also in the crisis sub-period for spot returns. Findings therefore suggest that spot returns are more predictable based on the past volatilities, which is indicated by their higher coefficients. The Brent oil market is characterised by being volatile with the occurrence of large shocks, which are due to economic, political or financial causes. The GARCH (1, 1$)$ model shows higher spikes and lower persistency during direct oil supply/demand shocks such as the Gulf war and the US terrorist attack in 2001. The economic or financial shocks during the Asian Crisis and the Global Financial Crisis have higher persistence and lower volatility spikes, meaning that the uncertainty and the risk in the oil market lasted longer. This is a significant insight for hedging strategies as during direct supply/demand shocks shorter hedges could be applied when compared to longer hedging strategies during economic/financial crises. 
Table 5

Volatility models for the September 11, 2001.

Volatility models

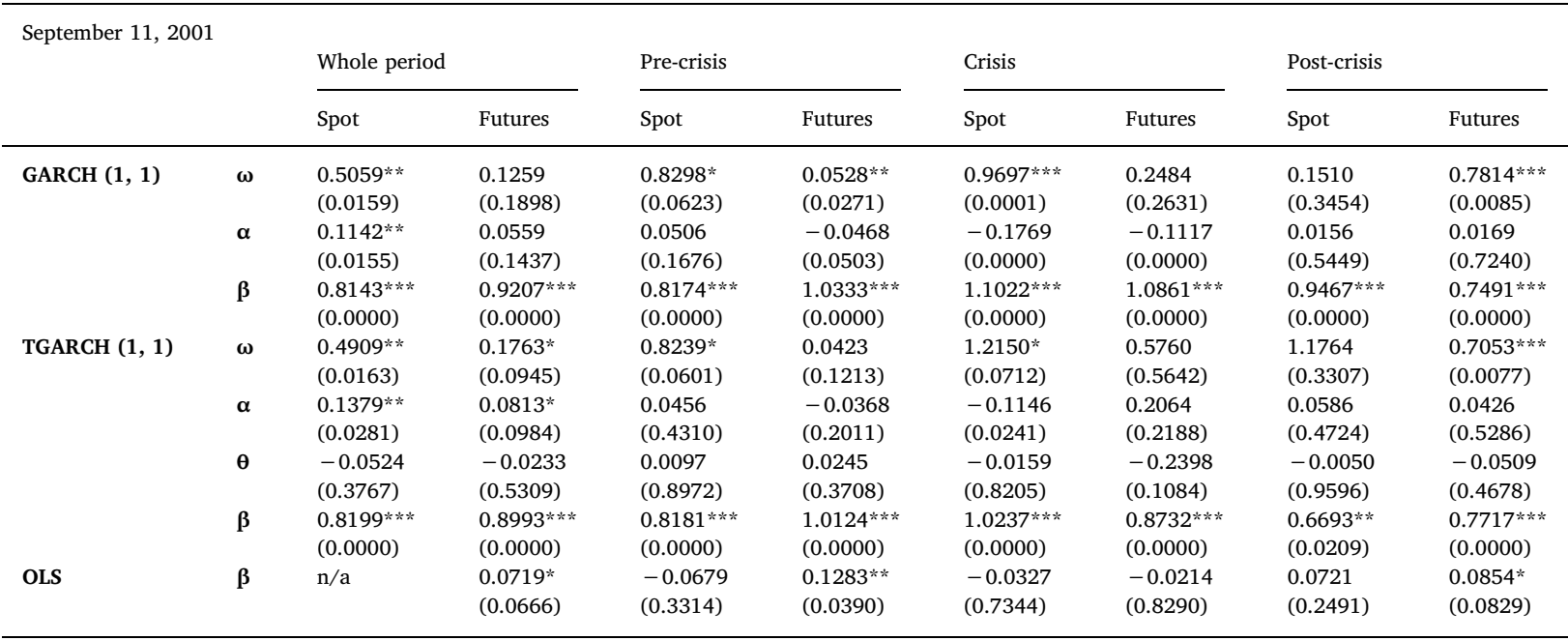

Note: $* * * * *, *$ represents statistical significance at $99 \%, 95 \%$ and $90 \%$ respectively. The OLS test was used to model.

volatility, not the returns, in cases where there was no ARCH effect in the series and in samples below 500. n/a menas 'not applied'.

Table 6

Volatility models for the Global Financial crisis.

\begin{tabular}{|c|c|c|c|c|c|c|c|c|c|}
\hline \multicolumn{10}{|l|}{ Volatility models } \\
\hline \multicolumn{10}{|c|}{ The Global Financial crisis } \\
\hline & & \multicolumn{2}{|c|}{ Whole period } & \multicolumn{2}{|l|}{ Pre-crisis } & \multicolumn{2}{|l|}{ Crisis } & \multicolumn{2}{|l|}{ Post-crisis } \\
\hline & & Spot & Futures & Spot & Futures & Spot & Futures & Spot & Futures \\
\hline \multirow[t]{4}{*}{ GARCH $(1,1)$} & $\omega$ & $0.0159 * *$ & $0.0273^{* * *}$ & $0.4967^{*}$ & $0.1630^{*}$ & -0.0209 & 0.0371 & $0.0272^{* *}$ & $0.0314 * *$ \\
\hline & & $(0.0471)$ & $(0.0068)$ & $(0.0698)$ & $(0.0533)$ & $(0.3990)$ & $(0.3617)$ & $(0.0476)$ & $(0.0401)$ \\
\hline & $\alpha$ & $\begin{array}{l}0.0412^{* * *} \\
(0.0000)\end{array}$ & $\begin{array}{l}0.0468^{* * * *} \\
(0.0000)\end{array}$ & $\begin{array}{l}0.0571^{* *} \\
(0.0437)\end{array}$ & $\begin{array}{l}0.0424 * * \\
(0.0237)\end{array}$ & $\begin{array}{l}-0.0164 \\
(0.5584)\end{array}$ & $\begin{array}{l}0.0542^{* *} \\
(0.0135)\end{array}$ & $\begin{array}{l}0.0541^{* * * *} \\
(0.0000)\end{array}$ & $\begin{array}{l}0.0514^{* * * *} \\
(0.0001)\end{array}$ \\
\hline & $\beta$ & $\begin{array}{l}0.9558^{* * *} \\
(0.0000)\end{array}$ & $\begin{array}{l}0.9462^{* * *} \\
(0.0000)\end{array}$ & $\begin{array}{l}0.8391^{* * *} \\
(0.0000)\end{array}$ & $\begin{array}{l}0.9138^{* * *} \\
(0.0000)\end{array}$ & $\begin{array}{l}1.0317^{* * *} \\
(0.0000)\end{array}$ & $\begin{array}{l}0.9489^{* * *} \\
(0.0000)\end{array}$ & $\begin{array}{l}0.9358^{* * *} \\
(0.0000)\end{array}$ & $\begin{array}{l}0.9372^{* * *} \\
(0.0000)\end{array}$ \\
\hline \multirow[t]{5}{*}{ TGARCH $(1,1)$} & $\omega$ & 0.0181 ** & $0.0313^{* * * *}$ & $0.4174^{* * *}$ & $0.2058^{*}$ & 0.0164 & $0.0579 * *$ & $0.0229^{*}$ & $0.0389 * *$ \\
\hline & & $(0.0269)$ & $(0.0042)$ & $(0.0215)$ & $(0.0527)$ & $(0.6956)$ & $(0.0170)$ & $(0.0812)$ & $(0.0345)$ \\
\hline & $\alpha$ & $\begin{array}{l}0.0129 \\
(0.1473)\end{array}$ & $\begin{array}{l}0.0281^{* *} \\
(0.0128)\end{array}$ & $\begin{array}{l}-0.0310 \\
(0.1376)\end{array}$ & $\begin{array}{l}0.0078 \\
(0.7329)\end{array}$ & $\begin{array}{l}-0.0317 \\
(0.2516)\end{array}$ & $\begin{array}{l}-0.0628 \\
(0.0019)\end{array}$ & $\begin{array}{l}0.0294 \\
(0.1253)\end{array}$ & $\begin{array}{l}0.0284 \\
(0.1630)\end{array}$ \\
\hline & $\theta$ & $\begin{array}{l}0.0487^{* * *} \\
(0.0004)\end{array}$ & $\begin{array}{l}0.0359^{* *} \\
(0.0105)\end{array}$ & $\begin{array}{l}0.1229^{* * *} \\
(0.0006)\end{array}$ & $\begin{array}{l}0.0549 * \\
(0.0684)\end{array}$ & $\begin{array}{l}0.0311 \\
(0.2156)\end{array}$ & $\begin{array}{l}0.0774^{* * *} \\
(0.0011)\end{array}$ & $\begin{array}{l}0.0409^{*} \\
(0.0542)\end{array}$ & $\begin{array}{l}0.0593^{* *} \\
(0.0156)\end{array}$ \\
\hline & $\beta$ & $\begin{array}{l}0.9587^{* * *} \\
(0.0000)\end{array}$ & $\begin{array}{l}0.9455^{* * *} \\
(0.0000)\end{array}$ & $\begin{array}{l}0.8807 * * * \\
(0.0000)\end{array}$ & $\begin{array}{l}0.9089 * * * \\
(0.0000)\end{array}$ & $\begin{array}{l}1.0240 * * * \\
(0.0000)\end{array}$ & $\begin{array}{l}1.0233^{* * *} \\
(0.0000)\end{array}$ & $\begin{array}{l}0.9414^{* * * *} \\
(0.0000)\end{array}$ & $\begin{array}{l}0.9285^{* * *} \\
(0.0000)\end{array}$ \\
\hline OLS & $\beta$ & $\mathrm{n} / \mathrm{a}$ & $\mathrm{n} / \mathrm{a}$ & $\mathrm{n} / \mathrm{a}$ & $\begin{array}{l}0.1407^{* * *} \\
(0.0000)\end{array}$ & $\begin{array}{l}0.1276^{* *} \\
(0.0140)\end{array}$ & $\begin{array}{l}0.1210^{* *} \\
(0.0199)\end{array}$ & $\mathrm{n} / \mathrm{a}$ & $\begin{array}{l}0.0972^{* * *} \\
(0.0005)\end{array}$ \\
\hline
\end{tabular}

Note: ***,**, *represents statistical significance at $99 \%, 95 \%$ and $90 \%$ respectively. The OLS test was used to model.

volatility, not the returns, in cases where there was no ARCH effect in the series and in samples below 500. n/a menas 'not applied'.

\section{Conclusions}

The risks involved with high levels of volatility in oil prices influence the decision-making process of investors, speculators and policy makers. The findings from this study show that during times of direct oil supply/demand disruptions (such the ones that took place during the Gulf war and 2001 US terrorist attack period), the series exhibited higher volatility spikes. This is in comparison to volatility behaviour during the Asian and the Global Financial Crises that had an indirect impact on the oil market, through the financial markets, where higher volatility persistence occurred. Consequently, the nature of the crisis plays a significant role in determining the behaviour of oil spot and futures prices and their lasting effects in terms of prolonged levels of uncertainty. As such, relevant market players should be aware that the crisis trigger can denote significant differences in the magnitude of the reaction of oil prices to the market shock. Supply and demand related shocks are associated with higher levels of uncertainty, while economic and financial crises exhibit longer levels of persistence. The research outcomes have major implications with regard to the time 
horizon that should be considered by market players when designing their hedging strategies. Future research in the field should aim to explore the nature and triggers of crisis episodes as this would facilitate a better understanding of oil price dynamics.

\section{Appendix}

Table A

Out of Sample T-GARCH $(1,1)$ results.

\begin{tabular}{llll}
\hline & & Brent Returns & \\
\cline { 3 - 4 } & & Spot & Futures \\
\hline TGARCH $(1,1)$ & $\omega$ & $0.008^{*}$ & $0.019^{* * *}$ \\
& $\alpha$ & $(0.058)$ & $(0.005)$ \\
& & -0.003 & 0.015 \\
& $\theta$ & $(0.632)$ & $(0.160)$ \\
& $\beta$ & $0.065^{* * *}$ & $0.063^{* * *}$ \\
& & $(0.000)$ & $(0.000)$ \\
& & $0.965^{* * *}$ & 0.942 \\
& & $(0.000)$ & $(0.000)$ \\
\hline
\end{tabular}

Note: $* * * *$ represents statistical significance at $99 \%$ and $90 \%$ respectively.

Tested period from $12 / 2 / 2014$ to $29 / 7 / 2015$.

\section{Supplementary material}

Supplementary material associated with this article can be found, in the online version, at doi:10.1016/j.frl.2018.12.026.

\section{References}

Bollerslev, T., 1986. Generalised autoregressive conditional heteroskedasticity. J. Econom. 31, 307-327.

Charles, A., Darné, O., 2014. Volatility persistence in crude oil markets. Energy Policy 65, 729-742.

Diaz, E.M., de Gracia, F.P., 2017. Oil price shocks and stock returns of oil and gas corporations. Finance Res. Lett. 20 , 75-80.

Dowling, M., Cummins, M., Lucey, B.M., 2016. Psychological barriers in oil futures markets. Energy Econ. 53, $293-304$.

Engle, R.F., 1982. Autoregrresive conditional heteroskedasticity with estimates of the variance of United Kingdom inflation. Econometrica $50,987-1007$.

Evgenidis, A., 2018. Do all oil price shocks have the same impact? Evidence from the Euro Area. Finance Res. Lett. 26, $150-155$.

Fiorentini, G., Sentana, E., Calzolari, G., 2004. On the validity of the Jarque-Bera normality test in conditionally heteroskedastic dynamic regression models. Econ. Lett. 83, 307-312.

Hamilton, J.D., 2014. The Changing Face of World Oil Markets. National Bureau of Economic Research (No. w20355).

Johnson, L.L., 1960. The theory of hedging and speculation in commodity futures. Rev. Econ. Stud. 27, $139-151$.

Lee, J., List, J.A., Strazicich, M., 2006. Non-renewable resource prices: deterministic or stochastic trends? J. Environ. Econ. Manage. 51, 354-370.

Morales, L., Andreosso-O'Callaghan, B., 2014. Volatility analysis on precious metals returns and oil returns: an ICSS approach. J. Econ. Finance 38, $492-517$.

Narayan, P.K., Narayan, S., 2007. Modelling oil price volatility. Energy Policy 35 (12), 6549-6553.

Oberndorfer, U., 2009. Energy prices, volatility, and the stock market: evidence from the Eurozone. Energy Policy 37, 5787-5795.

Orbaneja, J.R.V., Iyer, S.R., Simkins, B.J., 2018. Terrorism and oil markets: a cross-sectional evaluation. Finance Res. Lett. 24 , $42-48$.

Ozdemir, A.Z., Gokmenoglu, K., Ekinci, C., 2013. Persistence in crude oil spot and futures prices. Energy 59, $29-37$.

Robe, M., Wallen, J., 2016. Fundamentals, derivatives market information and oil price volatility. J. Futures Markets 36 (4), 317-344.

Sadorsky, P., 2006. Modelling and forecasting petroleum futures volatility. Energy Econ. 28, 467-488.

Salisu, A.A., Fasanya, I.O., 2013. Modelling oil price volatility with structural breaks. Energy Policy 52, 554-562.

Wang, Y., Wu, C., 2012. Forecasting energy market volatility using GARCH models: can multivariate models beat univariate models? Energy Econ. 34, $2167-2181$. Wang, Y., Wu, C., Yang, L., 2016. Forecasting crude oil market volatility: a Markov switching multifractal volatility approach. Int. J. Forecasting 32, 1-9.

Zakoian, J.M., 1994. Threshold heteroskedasticity models. J. Econ. Dyn. Control 18, 931-944.

Zhang, Z., 2009. Analysis of Skewness in GARCH Models. School of Economics and Social Sciences, Hogskolan Dalama.

Zhang, Y.-J., Wang, Z.-Y., 2013. Investigating the price discovery and risk transfer functions in the crude oil and gasoline futures markets: some empirical evidence.

Appl. Energy 104, 220-228.

Zivot, E., 2009. Practical issues in the analysis of univariate GARCH models. Handbook of Financial Time Series. Pringer, Berlin, Heidelberg, pp. 113-155. 